\title{
Occurrence of Peneopsis serrata (Bate, 1881) (Decapoda, Penaeidae) in the Mediterranean Sea
}

\author{
P. Abelló (*) and P. Torres $(* *)$
}

Peneopsis serrata (Bate, 1881) is a peneid shrimp whose distribution area encompasses both sides of the northern subtropical Atlantic Ocean, from North Carolina to Surinam, including the Bahamas, Gulf of Mexico and Caribbean, in the western Atlantic, and from South Portugal to Rio de Oro in the eastern Atlantic (Lagardère, 1971; Crosnier \& Forest, 1973; Holthuis, 1980; Noël, 1992), excluding, to date, the Mediterranean Sea.

The species was not included in ZariquieyÁlvarez's (1968) posthumous work on the fauna of decapod crustaceans from the Iberian Peninsula. Maurin (1962), however, indicated that Peneopsis serrata was rather common off the south coasts of Portugal and Spain west of Gibraltar. This author also stated that, despite intensive sampling off the Mediterranean northern coasts of Africa between the Strait of Gibraltar and Tunisia, P. serrata was not found to occur in Mediterranean waters. Later on, other authors (Sardá et al., 1982; García-Raso, 1996; López de la Rosa, 1997) have also reported the occurrence of the species in nearby Atlantic areas, west of the strait of Gibraltar. Faunistic studies on the Alborán Sea fauna had also failed to report $P$. serrata from the Mediterranean Sea (Miranda y Rivera, 1933; Sietti, 1933; García-Raso, 1982, 1984, 1985, 1989; García-Raso \& SalasCasanova, 1984), although it must be stated that most of these studies were focused on the littoral and shallow-water fauna.

The present note aims to report the occurrence of Peneopsis serrata in the Mediterranean Sea, in the vicinity of the island of Alborán.

\section{Material examined}

Peneopsis serrata (Bate, 1881)

One adult female, $19.5 \mathrm{~mm}$ carapace length, was captured on the 11 February 1997 by trawling in the vicinity of the island of Alborán (initial position of the haul: $35^{\circ} 56.18 \mathrm{~N}, 3^{\circ} 08.04 \mathrm{~W}$ ) from a depth of $378 \mathrm{~m}$. The sample was taken within the frame of a fisheries research cruise ("REINBAM 9702") performed on board B/O "Cornide de Saavedra". The specimen has been deposited in the Biological Collections of Reference of the Instituto de Ciencias del Mar (CSIC) in Barcelona (Spain) with the code number ICMD-259/1997.

The species is known from nearby areas in the Eastern Atlantic Ocean, such as the Gulf of Cadiz and southern Portugal, west of the Strait of Gibraltar (Sardá et al., 1982; Ribeiro-Cascalho, 1987; García-Raso, 1996; López de la Rosa, 1997), and its occurrence in waters around the Canary Islands is also probable (González-Pérez, 1995). Crosnier \& Forest (1973) indicated that the species appeared to be commoner in subtropical rather than tropical regions off West Africa. The individual studied herein constitutes the first reported occurrence of Peneopsis serrata in the Mediterranean Sea, east of the Strait of Gibraltar.

The depth of occurrence of this present specimen $(378 \mathrm{~m})$ fits well within the depth range reported for the species in nearby areas of the Atlantic: 120-640 m (Bouvier, 1908; Lagardère, 1971; Holthuis, 1980; Noël, 1992), 180-600 m (Maurin, 1962), 200-700 m (Maurin, 1963; Crosnier \&

\footnotetext{
* Institut de Ciències del Mar (CSIC), Passeig Joan de Borbó s/n, 08039 Barcelona, Spain.

** Centro Oceanográfico de Málaga (IEO), Puerto Pesquero s/n, 29640 Fuengirola (Málaga), Spain.
} 
Forest, 1973), 150-600 m (Maurin, 1965), 351-457 m (Sardá et al., 1982), 347-491 m (García-Raso, 1996)

From the biogeographical point of view, it must be remarked that the Alborán Sea (the westernmost area of the Mediterranean Sea) has a strong Atlantic influence due to the particular hydrographical regime taking place in the area: there is a surface influx of Atlantic water entering the Mediterranean through the Gibraltar Strait and a deeper outflux of Mediterranean water into the Atlantic Ocean (Hopkins, 1985). The occurrence of Peneopsis serrata in Alborán Sea may be due to the influx of epipelagic larvae entering the Mediterranean through surface waters, since the deep currents would not favour the influx of adult individuals. It is still too early to ascertain whether P. serrata forms well-established populations and performs its whole life cycle within the Mediterranean or whether its presumed population in Alborán Sea constitutes a "pseudopopulation" sensu Bouchet \& Taviani (1992), in which the adult specimens of a species are not able to reproduce due to the particular environmental characteristics of the Mediterranean Sea, in particular the high temperature of the deep water $\left(12-13^{\circ} \mathrm{C}\right)$, and the populations are therefore maintained only by the larval influx from the Atlantic.

\section{ACKNOWLEDGEMENTS}

We wish to thank all participants in the cruise "REINBAM 9702" on board B/O "Cornide de Saavedra", and especially its Chief Scientist, Mr. Luis Gil de Sola, for all his support.

\section{References}

Bouchet, P. \& Taviani, M., 1992. The Mediterranean deep-sea fauna: pseudopopulations of Atlantic species? Deep-Sea Research, 39: 169-184.

Bouvier, E.L., 1908. Quelques observations systématiques sur la sous famille des Penaeinae Alcock. Bulletin du Muséum Océanographique de Monaco, 119: 1-10.

Crosnier, A. \& Forest, J., 1973. Les crevettes profondes de l'Atlantique oriental tropical. Faune Tropicale ORSTOM, Paris, 19: 1-409.

García-Raso, J.E., 1982. Penaeidea y Caridea de las costas de Málaga (región sur-mediterránea española). Graellsia, 38: 85-115.

GARCíA-RASO, J.E., 1984. Primeras aportaciones al conocimiento de la fauna de Crustáceos Decápodos litorales de la Isla de Alborán (España). Boletín de la Asociación Española de Entomología, 8: 253-263.
GarcíA-RAso, J.E., 1985. Nuevas aportaciones a la fauna de crustáceos decápodos de la isla de Alborán (España). Boletim da Sociedade Portuguesa de Entomologia, Supl. 1, 1: 11-18.

GARCíA-RASO, J.E., 1989. Resultados de la segunda campaña del I.E.O. para la exploración de los fondos de Coral Rojo en el Mar de Alborán. Crustáceos Decápodos. Boletín del Instituto Español de Oceanografía, 5: 27-36.

García-Raso, J.E., 1996. Crustacea Decapoda (excl. Sergestidae) from Ibero-Moroccan waters. Results of Balgim-84 expedition. Bulletin of Marine Science, 58: 730-752.

García-Raso, J.E. \& Salas-Casanova, C., 1984. Aportaciones al conocimiento de la fauna y flora litoral de la Isla de Alborán (España). Jábega, 45: 76-80.

GonzÁlez-PÉrez, J.A., 1995. Catálogo de los crustáceos decápodos de las islas Canarias. Gambas. Langostas. Cangrejos. Publicaciones Turquesa. Santa Cruz de Tenerife. 282 pp.

Holthuis, L.B., 1980. FAO species catalogue. Vol. 1. Shrimps and prawns of the world. An annotated catalogue of species of interest to fisheries. FAO Fisheries Synopses, 125(1): 1-271.

Hopkins, T.S., 1985. Physics of the sea. In: R. Margalef (ed.). Key Environments: Western Mediterranean. Pergamon Press. Oxford: 100-125.

LAGARDÈRE, J.-P., 1971. Les crevettes des côtes du Maroc. Travaux de l'Institut Scientifique Chériffien et de la Faculté des Sciences, Série Zoologie, 36: 1-140.

LÓPEZ DE LA RosA, I., 1997. Crustáceos decápodos capturados durante las campañas del IEO ARSA0393 y ARSA1093 en el golfo de Cádiz: distribución batimétrica. Publicaciones Especiales Instituto Español de Oceanografia, 23: 199-206.

Maurin, C., 1962. Étude des fonds chalutables de la Méditerranée occidentale (écologie et pêche). Résultats des campagnes des navires océanographiques "Président Théodore Tissier" 1957 à 1960 et "Thalassa" 1960 et 1961. Revue des Travaux Institut Pêches maritimes, 26(2): 163-218.

MAURIN, C., 1963. Les crevettes capturées par la "Thalassa" au large des Côtes du Rio de Oro et de Mauritanie. Écologie et pêche. CIEM, Comité des Mollusques et Crustacés, CM 1963, no 48: 1-4.

MAUrin, C., 1965. Les crevettes profondes de la région Atlantique ibéro-marocaine: repartition bathymétrique et géographique, importance économique. Rapports Conseil Exploration Mer, 156: 116-119.

MirAndA y RiverA, A., 1933. Ensayo de un catálogo de los Crustáceos Decápodos marinos de España y Marruecos español. Notas y Resumenes, Boletín Instituto Español de Oceanografia, ser. II, 67: 1-72.

NoËL, P.Y., 1992. Clé préliminaire d'identification des Crustacea Decapoda de France et des principales 
autres espèces d'Europe. Muséum National d'Histoire Naturelle. Paris. 146 pp.

Ribeiro-CascalHo, A., 1987. The decapod crustaceans in crustacean fishing grounds from the South coast of Portugal. Investigación Pesquera, 51 (Supl. 1): 261262.

Sardá, F, Valladares, F.J. \& Abelló, P., 1982. Crustáceos decápodos y estomatópodos capturados durante la campaña "Golfo de Cádiz 81". Resultados Expediciones Científicas (Suplemento Investigación Pesquera), 10: 89-100.
SIETTI, H., 1933. Nouvelle contribution à l'histoire naturelle de l'île d'Alborán. Bulletin Société Sciences Naturelles Maroc, 13(1-3): 10-22.

Zariquiey-Álvarez, R., 1968. Crustáceos decápodos ibéricos. Investigación Pesquera, 32: 1-510.
Recibido, el 23-II-1998

Aceptado, el 16-XI-1998 Publicado, el 31-XII-1998 